\title{
HUBUNGAN FUNGSI KELUARGA DAN PERAN TEMAN SEBAYA DENGAN PERILAKU BULLYING PADA REMAJA DI SMAN 5 DEPOK
}

\section{RELATIONSHIP OF FAMILY FUNCTIONS AND ROLE OF PEER WITH BULLYING BEHAVIOR IN TEENAGERS AT SMAN 5 DEPOK}

\author{
Puspita Lestari $^{1}$, Diah Ratnawati ${ }^{2}$, Duma Lumban Tobing ${ }^{3}$ \\ Fakultas Ilmu Kesehatan, Universitas Pembangunan Nasional Veteran Jakarta ${ }^{1}, 2,3$
}

\begin{abstract}
ABSTRAK
Fenomena bullying dilingkungan remaja kembali menjadi pusat perhatian publik. Bullying merupakan penyalahgunaan kekuasaan yang senantiasa dilakukan oleh seorang anak atau lebih dengan tujuan melukai perasaan/ membuat tertekan yang bisa dilakukan secara berkali-kali. Penelitian ini bertujuan untuk mengetahui hubungan antara fungsi keluarga dan peran teman sebaya dengan perilaku bullying pada remaja di SMAN 5 Depok. Penelitian menggunakan uji Chi Square dengan pendekatan deskriptif analitik cross sectional, sampel berjumlah 167 remaja dan pengambilan sampel dilakukan dengan teknik Stratified random sampling. Hasil penelitian didapatkan adanya hubungan positif antara fungsi keluarga dengan perilaku bullying pada remaja di SMAN 5 depok didapatkan $p$ value 0,030 dengan $\mathrm{OR}=2,078$, ini artinya fungsi keluarga kurang baik memiliki peluang 2,078 kali untuk positif melakukan perilaku bullying. Selain itu, ada hubungan positif antara peran teman sebaya dengan perilaku bullying pada remaja didapatkan $\mathrm{p}$ value $=$ 0,008 dengan $\mathrm{OR}=2,430$, ini artinya peran teman sebaya kurang baik memiliki peluang 2,430 kali untuk positif melakukan perilaku bullying. Peneliti menyarankan remaja supaya lebih menghargai sesama teman, dengan cara tidak menyakiti atau mengejek teman yang lain dan menjauhi bentuk Bullying fisik, psikologis, verbal maupun cyberbullying.
\end{abstract}

Kata Kunci: bullying, remaja, fungsi keluarga dan peran teman sebaya

\begin{abstract}
The phenomenon of bullying within adolescents has reemerge to the center of public attention. Bullying is abuse of power that is always carried out by a child or a group of child to injure feelings or to distress. This research purpose is to determine the relationship between family function and role of peers with bullying in teenagers at SMAN 5 Depok. This Research uses the Chi-Square test with a descriptive approach of cross-sectional analytic. Total samples are 167 teenagers, and was carried out using a Stratified random sampling technique. The results of the study obtained a positive relationship between family function and bullying behavior in teenagers in SMAN 5 Depok with a p-value 0.030 with $O R=2.078$. This means that the function of family had a chance of 2.078 times to positively conduct bullying behavior. While there is a positive relationship between peer roles and bullying behavior in teenagers with $p$-value $=0.008$ with $O R=2.430$. This means the role
\end{abstract}


Bali Medika Jurnal.

Vol 7 No 2, 2020: 234-244

ISSN : 2615-7047

DOI: https://doi.org/10.36376/bmj.v7i2

of poor peers is 2.430 times to positively conduct bullying behavior. Researchers advise teenagers to better appreciate their peers, by not hurting or ridiculing other friends and avoiding physical, psychological, verbal and cyberbullying forms.

Keywords: bullying in teenagers, family function and peer role

\begin{tabular}{lll}
\hline Alamat Korespondensi & Fakultas Ilmu Kesehatan, Universitas Pembangunan \\
& Nasional Veteran Jakarta, Jalan Limo Raya Kelurahan \\
& Limo Kecamatan Limo Kota Depok Kode Pos 16515 \\
Email & $:$\begin{tabular}{l} 
ratnawatidiah@yahoo.co.id \\
\hline
\end{tabular}
\end{tabular}

\section{PENDAHULUAN}

Fenomena bullying dilingkungan remaja kembali menjadikan pusat perhatian publik. Bullying merupakan perilaku kurang baik dikarenakan orang yang kuat memaksa, melecehkan, memojokkan dan melukai secara berkali-kali kepada orang yang lebih lemah (Wiyani, 2012). Jenis-jenis perilaku bullying verbal seperti menghina, meneriaki, memberikan julukan nama, celaan, fitnah, mempermalukan didepan umum, menghina.

Bullying berupa fisik seperti memukul, mencekik, menyikut, meminju. Cyberbullying seperti mendapatkan ancaman atau pesan negatif melalui media sosial seperti SMS, line, WA, Instagram, Fb, Twitter dan lain-lain. Bullying mental seperti pengabaian, pengucilan, atau peghindaran. (Ningrum, Matulessy, \& Rini, 2019; Zakiyah, Humaedi, \& Santoso, 2017). Prevalensi perundungan terjadi dibeberapa negara eropa, amerika dan asia dengan presentase 8 sampai $50 \%$ (Wakhid, Andriani, \& Saparwati, 2019).

Sesuai dengan data dari Departemen Pendidikan Amerika Serikat mengungkapkan remaja berusia antara 12 hingga 18 tahun adalah korban bullying yang berkisar 22\% (Aminah \& Nurdianah, 2019). Jurnal Empati berdasarkan survey yang dilakukan Latitude News terhadap 40 negara mengungkapkan kasus bullying menjadikan Indonesia menempati posisi kedua setelah Jepang dengan kasus perundungan yang sering terjadi, urutan selanjutnya Kanada, Korea Selatan, AS dan Finlandia (Febriyani \& Indrawati, 2017). Selain itu, Komisi Perlindungan Anak Indonesia (KPAI) mengungkapkan ditemukan sekitar 253 kasus perundungan yang ditemukan sejak tahun 2011 hingga 2016, yang menjadi korban kasus intimidasi ada 122 remaja dan menjadi pelaku 131 remaja (Ningrum dkk., 2019).

Tingginya prevalensi Bullying tentu tidak lepas dari dampak yang ditemukan. Dampak negatif pada korban bullying berupa anak mengalami kecemasan, timbul perasaan tertekan, anak mengalami depresi akibat tekanan yang diberikan pelaku bullying, menurunnya fungsi sosial, kepercayaan diri menurun, rendahnya prestasi akademik, dan korban dapat mengasingkan diri dari lingkungan (Hermalinda, Deswita, \& Oktarina, 2017). Studi di Afrika Barat memaparkan bahwa korban bullying akan mengalami depresi 1,97 kali daripada yang tidak mengalami bullying dan 1,72 kali lebih besar untuk melakukan ide bunuh diri (Marela, Wahab, \& Marchira, 2017). 
Macam-macam yang mempengaruhi tingginya insiden bullying dapat berasal dari berbagai sektor, baik sekolah, lingkungan teman sebaya dan keluarga, maupun dari tahap perkembangan remaja itu sendiri.

Pertama, ini berbicara tentang perubahan fisik yang dilalui remaja dan kadang membuat mereka menjadi topik pembicaraan bahkan menyudutkan keadaan fisiknya, hal yang dilakukan tersebut sudah termasuk perilaku Bullying. Faktor kedua yaitu lingkungan teman sebaya. Bullying di Indonesia, sekitar 84\% remaja telah diintimidasi, yang dilakukan oleh teman sebayanya (Rohimah, 2016). Fataruba (2016) menyatakan bahwa survey yang di lakukan oleh Global Studentbased Health Survey (GSHS) menjelaskan bahwa di Indonesia 50\% anak berusia 13-15 tahun pernah menerima perilaku intimidasi yang terjadi disekolah yang telah dilakukan oleh tema.

Faktor ketiga yaitu fungsi keluarga, Schwab, Gray-Ice, \& Prentice (2002) menjelaskan bahwa, fungsi interaksi yang terjadi dialam keluarga ialah bertindak sebagai agen sosialisasi budaya dan nilai-nilai sosial kepada anak, pemberi afeksi, serta fungsi pengasuhan merupakan interaksi didalam keluarga. Keberfungsian keluarga atau keluarga yang fungsional ialah keluarga yang bisa memenuhi fungsinya dengan baik (Yusuf dalam Juliyanti \& Siswati, 2014).

Hasil studi pendahuluan di SMAN 5 Depok pada tanggal 19 Februari 2020, diperoleh hasil wawancara dan observasi yang peneliti lakukan pada 12 siswa kelas $\mathrm{X}$ dan XI, peneliti menemukan beberapa kasus perundungan, semua siswa yang diwawancara mengatakan pernah mengalami kasus bullying, 8 orang menceritakan bullying yang mereka terima ada bullying verbal berupa ejekan, sindiran, serta dibentak lalu 2 siswa mengatakan pernah menjadi korban bullying fisik seperti dipukul atau ditampar. Ada sebanyak 3 orang siswa pernah menjadi pelaku bullying 1 disebabkan karena orangtua yang berpisah dan 1 siswa mengatakan menjadi pelaku dikarenakan keluarganya yang tidak harmonis serta orangtua yang terlalu ketat terhadap anaknya. Studi Pendahuluan yang dilakukan peneliti kepada remaja di SMAN 5 Depok mengatakan remaja yang diintimidasi merasa sedih, malu, tidak nyaman, merasa takut, rendah diri, merasa tidak berharga, dendam untuk membalas , bahkan ada yang sampai ingin pindah sekolah.

Disisi lain, 3 siswa yang pernah dilecehkan mengatakan menjadi pelaku bullying karena ingin membalas dendam serta mengikuti temannya agar mereka bisa dihargai dan menjadi sahabatnya. Salah satu tugas perawat dalam menangani kasus perundungan pada remaja dengan memperluas pengetahuan remaja kearah yang lebih positif serta menjadi edukator sebagai upaya preventif untuk mencegah adanya dampak perilaku negatif dari perilaku bullying. Penelitian ini juga berbeda dari penelitian yang pernah ada, dimana peneliti menggabungkan fungsi keluarga dan peran teman sebaya, subjek dan sampel yang dugunakan juga berbeda dari penelitian sebelumnya. dimana Penelitian ini bertujuan untuk mengetahui Hubungan Fungsi keluarga dan Peran Teman Sebaya dengan Perilaku Bullying pada Remaja di SMA Negeri 5 Depok.

\section{METODE PENELITIAN}

Penelitian ini merupakan jenis penelitian deskriptif analitik dengan pendekatan kuantitatif yaitu mengukur variabel yang telah ditentukan dan mencari hubungan antar variabel dari fenomena yang diteliti. Desain penelitian ini adalah 
cross-sectional. Penelitian ini dilakukan di SMAN 5 Depok, waktu penelitian dari bulan April sampai Juni 2020. Pengambilan sampel dilakukan dengan startified random sampling dengan jumlah 167 responden yang memiliki kriteria sebagai berikut: siswa/i yang duduk dibangku kelas X dan XI dan remaja berusia 14 sampai dengan 17 tahun. Pengambilan data dilakukan dengan kuesioner melalui form online yang disebar melalui grup kelas serta kordinator dengan ketua osis dan ketua kelas. Kuesioner terdiri dari 3 bagian yaitu fungsi keluarga dengan kuesioner menurut model McMaster Family Assesment Device (FAD), peran teman sebaya dan perilaku bullying yang telah dilakukan uji validitas dan reliabilitas.

\section{HASIL}

\section{HASIL DAN PEMBAHASAN}

Tabel 1. Distribusi Frekuensi Karakteristik Berdasarkan Usia Responden $(n=167)$

\begin{tabular}{ccc}
\hline \multicolumn{1}{c}{ Variabel } & Frekuensi & Persentase (\%) \\
\hline Usia & 12 & 7,2 \\
Remaja awal (13-15 tahun) & 155 & 92,8 \\
Remaja pertengahan (15-17 tahun) & & \\
Total & $\mathbf{1 6 7}$ & $\mathbf{1 0 0}$ \\
\hline
\end{tabular}

Tabel 1 diatas, karakteristik usia responden berada pada usia remaja pertengahan sebanyak 155 remaja $(92,8 \%)$, sedangkan pada usia remaja awal diperoleh sebanyak 12 remaja (7,2\%). Mayoritas responden pada penelitian ini adalah berusia remaja pertengahan.

Tabel 2. Distribusi Frekuensi Karakteristik Berdasarkan Jenis Kelamin Responden $(n=167)$

\begin{tabular}{ccc}
\hline Variabel & Frekuensi & Persentase (\%) \\
\hline Jenis Kelamin & 65 & $38,9 \%$ \\
Laki-laki & 102 & $61,1 \%$ \\
Perempuan & $\mathbf{1 6 7}$ & $\mathbf{1 0 0}$ \\
Total & \\
\hline
\end{tabular}

Pada tabel 2 dapat dilihat bahwa karakteristik jenis kelamin responden dengan perilaku bullying adalah remaja perempuan dengan jumlah 102 remaja $(61,1 \%)$, sedangkan pada remaja laki-laki didapatkan sebanyak 65 remaja $(38,9 \%)$. Jadi sebagian besar responden berjenis kelamin perempuan. 
DOI: https://doi.org/10.36376/bmj.v7i2

Tabel 3. Distribusi Frekuensi Berdasarkan Fungsi Keluarga (n=167)

\begin{tabular}{ccc}
\hline Variabel & Frekuensi & Persentase (\%) \\
\hline Fungsi Keluarga & & \\
Kurang baik & 78 & 46,7 \\
Baik & 89 & 53,3 \\
Total & $\mathbf{1 6 7}$ & $\mathbf{1 0 0}$ \\
\hline
\end{tabular}

Tabel 3 memperlihatkan bahwa remaja dengan fungsi keluarga baik dengan jumlah 89 responden $(53,3 \%)$, sedangkan fungsi keluarga kurang baik yaiu 78 responden (46,7\%). Maka responden dengan fungsi keluarga baik lebih dominan.

Tabel 4. Distribusi Frekuensi Berdasarkan Peran Teman Sebaya $(n=167)$

\begin{tabular}{ccc}
\hline Variabel & Frekuensi & Persentase (\%) \\
\hline Peran Teman Sebaya & & \\
Kurang baik & 79 & 47,3 \\
Baik & 88 & 52,7 \\
Total & $\mathbf{1 6 7}$ & $\mathbf{1 0 0}$ \\
\hline
\end{tabular}

Tabel 4 menampilkan data responden yaitu remaja dengan peran teman sebaya kurang baik dengan 79 responden $(47,3 \%)$, sedangkan peran teman sebaya baik yaitu sebesar 88 responden (52,7\%). Oleh karena itu, responden lebih banyak dengan peran teman sebaya yang baik.

Tabel 5. Distribusi Frekuensi Berdasarkan Perilaku Bullying $(\mathrm{n}=167)$

\begin{tabular}{ccc}
\hline Variabel & Frekuensi & Persentase (\%) \\
\hline Perilaku Bullying & & \\
Positif & 74 & $44,3 \%$ \\
Negatif & 93 & $55,7 \%$ \\
Total & $\mathbf{1 6 7}$ & $\mathbf{1 0 0}$ \\
\hline
\end{tabular}

Tabel 5 menunjukkan hasil bahwa remaja yang negatif melakukan perilaku bullying yaitu $93(55,7 \%)$ responden, sedangkan remaja yang positif melakukan bullying sebanyak 74 responden (44,3\%). Oleh sebab itu, mayoritas responden yang negatif melakukan perilaku bullying.

Tabel 6. Hubungan Usia Dengan Perilaku Bullying $(n=167)$

\begin{tabular}{|c|c|c|c|c|c|c|c|c|}
\hline \multirow{3}{*}{ Usia } & \multicolumn{4}{|c|}{ Perilaku Bullying } & \multicolumn{2}{|c|}{ Total } & \multirow{3}{*}{$\begin{array}{c}\text { OR } \\
(95 \% \\
\text { CI })\end{array}$} & \multirow{3}{*}{$\begin{array}{c}\mathbf{p} \\
\text { valu } \\
e\end{array}$} \\
\hline & \multicolumn{2}{|c|}{ Positif } & \multicolumn{2}{|c|}{ Negatif } & & & & \\
\hline & $\mathbf{N}$ & $\%$ & $\mathbf{N}$ & $\%$ & $\mathbf{N}$ & $\%$ & & \\
\hline $\begin{array}{l}\text { Remaja } \\
\text { Awal (13- } \\
15 \text { Tahun) }\end{array}$ & 5 & $41,7 \%$ & 7 & $58,3 \%$ & 12 & 100 & 0,890 & $\begin{array}{c}1,00 \\
0\end{array}$ \\
\hline
\end{tabular}




\begin{tabular}{cccccccc}
\hline $\begin{array}{c}\text { Remaja } \\
\text { Pertengaha } \\
\text { n (15-17 } \\
\text { Tahun) }\end{array}$ & 69 & $44,5 \%$ & 86 & $55,5 \%$ & 155 & 100 & $\begin{array}{c}(0,271- \\
2,928)\end{array}$ \\
Jumlah & 74 & $44,3 \%$ & 93 & $55,7 \%$ & 167 & 100 & \\
\hline
\end{tabular}

Hasil penelitian dari tabel 6 diatas menunjukan usia remaja awal (13-15 tahun) dengan perilaku bullying positif diperoleh hasil 5 remaja $(41,7 \%)$ dan negatif sebanyak 7 remaja $(58,3 \%)$. Selain itu, usia remaja pertengahan (15-17 tahun) dengan perilaku bullying positif diperoleh hasil $69(44,5 \%)$ dan negatif sebanyak 86 remaja (55,5\%). Hasil uji statistik diperoleh nilai $\mathrm{p}=1,000$ maka dapat disimpulkan tidak ada hubungan antara usia dengan perilaku bullying pada remaja.

Tabel 7. Hubungan Jenis Kelamin Dengan Perilaku Bullying $(\mathrm{n}=167)$

\begin{tabular}{|c|c|c|c|c|c|c|c|c|}
\hline \multirow{3}{*}{$\begin{array}{c}\text { Jenis } \\
\text { Kelamin }\end{array}$} & \multicolumn{4}{|c|}{ Perilaku Bullying } & \multicolumn{2}{|c|}{ Total } & \multirow{3}{*}{$\begin{array}{c}\text { OR } \\
(95 \% \\
\text { CI })\end{array}$} & \multirow{3}{*}{$\begin{array}{c}\mathrm{p} \\
\boldsymbol{v a l u} \\
\boldsymbol{e}\end{array}$} \\
\hline & \multicolumn{2}{|c|}{ Positif } & \multicolumn{2}{|c|}{ Negatif } & \multirow[b]{2}{*}{$\mathbf{N}$} & \multirow[b]{2}{*}{$\%$} & & \\
\hline & $\mathbf{N}$ & $\%$ & $\mathbf{N}$ & $\%$ & & & & \\
\hline Laki-laki & 31 & $47,7 \%$ & 34 & $52,3 \%$ & 34 & 100 & 1,251 & $\begin{array}{c}0,58 \\
8\end{array}$ \\
\hline Perempuan & 43 & $42,2 \%$ & 59 & $57,8 \%$ & 59 & 100 & $\begin{array}{c}(0,669- \\
2,339)\end{array}$ & \\
\hline Jumlah & 74 & $44,3 \%$ & 93 & $55,7 \%$ & 167 & 100 & & \\
\hline
\end{tabular}

Tabel 7 diatas menjelaskan hasil penelitian, jenis kelamin laki-laki dengan positif melakukan bullying berjumlah diperoleh hasil 31 remaja $(47,7 \%)$ dan negatif sebanyak 34 remaja (52,3\%), sedangkan, untuk jenis kelamin perempuan dengan positif melakukan bullying diperoleh hasil $43(42,2 \%)$ dan yang negatif sebanyak $59(57,8 \%)$ remaja perempuan. Hasil uji statistik diperoleh nilai $\mathrm{p}=0,58$ maka dapat disimpulkan tidak ada hubungan antara jenis kelamin dengan perilaku bullying pada remaja.

Tabel 8. Hubungan Fungsi Keluarga Dengan Perilaku Bullying $(n=167)$

\begin{tabular}{|c|c|c|c|c|c|c|c|c|}
\hline \multirow{3}{*}{$\begin{array}{c}\text { Fungsi } \\
\text { Keluarga }\end{array}$} & \multicolumn{4}{|c|}{ Perilaku Bullying } & \multicolumn{2}{|c|}{ Total } & \multirow{3}{*}{$\begin{array}{c}\text { OR } \\
(95 \% \\
\text { CI })\end{array}$} & \multirow{3}{*}{$\begin{array}{c}\mathbf{p} \\
\text { valu } \\
e\end{array}$} \\
\hline & & & & tif & & & & \\
\hline & $\mathbf{N}$ & $\%$ & $\mathbf{N}$ & $\%$ & $\mathbf{N}$ & $\%$ & & \\
\hline
\end{tabular}


DOI: https://doi.org/10.36376/bmj.v7i2

\begin{tabular}{ccccccccc}
\hline $\begin{array}{c}\text { Fungsi } \\
\text { Keluarga } \\
\text { Kurang } \\
\text { Baik }\end{array}$ & 42 & $53,8 \%$ & 36 & $46,2 \%$ & 78 & 100 & 2,078 & 0,03 \\
$\begin{array}{c}\text { Fungsi } \\
\text { Keluarga }\end{array}$ & 32 & $36 \%$ & 57 & $64,0 \%$ & 89 & 100 & $\begin{array}{c}(1,117- \\
3,867)\end{array}$ \\
$\begin{array}{c}\text { Baik } \\
\text { Jumlah }\end{array}$ & 74 & $44,3 \%$ & 93 & $55,7 \%$ & 167 & 100 & & \\
\hline
\end{tabular}

Pada tabel 8 menguraikan hasil penelitian berupa fungsi keluarga kurang baik dengan perilaku bullying positif diperoleh hasil 42 remaja $(53,8 \%)$ dan negatif sebanyak 36 remaja (46,2\%). Begitu juga didapatkan adanya fungsi keluarga baik dengan perilaku bullying positif diperoleh hasil 32 (36\%) dan negatif sebanyak 57 remaja (64\%). Hasil uji statistik diperoleh nilai $p=0,030$ maka dapat disimpulkan ada hubungan antara fungsi keluarga dengan perilaku bullying pada remaja.

Tabel 9. Hubungan Peran Teman Sebaya Dengan Perilaku Bullying $(\mathrm{n}=167)$

\begin{tabular}{|c|c|c|c|c|c|c|c|c|}
\hline \multirow{3}{*}{$\begin{array}{c}\text { Peran Teman } \\
\text { Sebaya }\end{array}$} & \multicolumn{4}{|c|}{ Perilaku Bullying } & \multicolumn{2}{|c|}{ Total } & \multirow{3}{*}{$\begin{array}{c}\text { OR } \\
(95 \% \\
\text { CI) }\end{array}$} & \multirow{3}{*}{$\begin{array}{c}\mathbf{p} \\
\text { valu } \\
e\end{array}$} \\
\hline & \multicolumn{2}{|c|}{ Positif } & \multicolumn{2}{|c|}{ Negatif } & \multirow[b]{2}{*}{$\mathbf{N}$} & \multirow[b]{2}{*}{$\%$} & & \\
\hline & $\mathbf{N}$ & $\%$ & $\mathbf{N}$ & $\%$ & & & & \\
\hline $\begin{array}{c}\text { Peran Teman } \\
\text { Sebaya } \\
\text { Kurang Baik }\end{array}$ & 44 & $55,7 \%$ & 35 & $44,3 \%$ & 79 & 100 & 2,430 & $\begin{array}{c}0,00 \\
8\end{array}$ \\
\hline $\begin{array}{c}\text { Peran Teman } \\
\text { Sebaya Baik }\end{array}$ & 30 & $34,1 \%$ & 58 & $65,9 \%$ & 88 & 100 & $\begin{array}{c}(1,300- \\
4,543)\end{array}$ & \\
\hline Jumlah & 74 & $44,3 \%$ & 93 & $55,7 \%$ & 167 & 100 & & \\
\hline
\end{tabular}

Tabel 9 diatas menjabarkan data tentang peran teman sebaya kurang baik dengan perilaku bullying positif diperoleh hasil 44 remaja $(55,7 \%)$ dan negatif sebanyak 35 remaja (44,3\%), sedangkan peran teman sebaya baik dengan perilaku bullying positif diperoleh hasil $30(34,1 \%)$ dan negatif sebanyak 58 remaja $(65,9 \%)$. Hasil uji statistik diperoleh nilai $\mathrm{p}=0,008$ maka dapat disimpulkan ada hubungan antara peran teman sebaya dengan perilaku bullying pada remaja.

\section{PEMBAHASAN}

\section{Hubungan Usia dengan Perilaku Bullying Pada Remaja di SMAN 5 Depok}

Hasil yang diperoleh menunjukkan usia responden dalam penelitian ini dari 14 hingga 17 tahun. Ini karena remaja masih sangat tidak stabil, karena ini adalah waktu untuk kesadaran diri ketika siswa memulai suatu hubungan. Keinginan kuat remaja untuk menjadi pusat perhatian juga mendorong mereka untuk melakukan hal-hal yang dapat menarik perhatian orang lain. Hal yang sama dikatakan oleh 
Putri (2015) bahwa kelompok usia 12-16 tahun dianggap lebih rentan terhadap bullying, karena perilaku bullying akan terjadi pada usia ini (Slonje \& Smith, 2008).

Salah satu bentuk perilaku menarik perhatian orang lain pada masa remaja, yaitu, intimidasi, remaja melakukannya untuk melakukannya dengan orang lain (Halimah, Khumas, \& Zainuddin, 2015). Akibatnya, remaja pertengahan secara positif terkait dengan bullying. Penelitian sejalan yang dilakukan Febriana (2018) (dalam Sakdiyah, Febriana, \& Setyowati, 2020) menyatakan bahwa intimidasi semakin meningkat dan merupakan jenis kekerasan yang biasa terjadi disekolah. selain itu, pada masa remaja tengah ini, remaja mulai merasa ingin bebas tetapi rentang usia kemampuan untuk mengambil tindakan belum sepenuhnya baik.

\section{Hubungan Jenis Kelamin Dengan Perilaku Bullying Pada Remaja di SMAN 5 Depok}

Beberapa penelitian yang pernah dilakukan menunjukkan perbedaan hasil yang signifikan berdasarkan gender. Namun, beberapa studi tidak menunjukkan adanya perbedaan yang signifikan antara gender dalam perilaku dan korban bullying (Morbidity and Mortality Weekly Report, 2011; Velki, 2012). Ini berarti, bahwa dalam hal ini keduanya memiliki porsi yang sama. Hal ini didukung oleh penelitian Fatmawati (2016) bahwa baik pria dan wanita tidak ada perbedaan dalam menunjukkan perilaku intimidasi.

Hal yang sama diungkapkan oleh Sitasari (2017) bahwa anak laki-laki lebih rentan terhadap penindasan fisik daripada anak perempuan, tetapi anak perempuan lebih cenderung melakukan penindasan verbal daripada laki-laki. Hasil ini sejalan dengan penelitian Nurhuda (Karina, Hastuti, \& Alfiasari, 2013), baik pria maupun wanita memiliki bagian yang sama dalam peran perundungan. Begitu juga penelitian yang dilakukan oleh Fatmawati (2016) bahwa tidak adanya perbedaan kecenderungan dalam perilaku bullying berdasarkan jenis kelamin.

\section{Hubungan Fungsi Keluarga Dengan Perilaku Bullying Pada Remaja di SMAN 5 Depok}

Keluarga adalah tempat untuk anak-anak belajar berperilaku dan membangun hubungan. Penelitian yang dilakukan oleh Wardani \& Fajriansyah (2017) berpendapat bullying dapat dipengaruhi oleh fungsi keluarga dan dukungan sosial. Hasil penelitian menunjukkan bahwa remaja yang kekurangan dukungan orangtua, seperti penyelesaian masalah, kurangnya komunikasi, dan kurangnya dorongan atau pemberian semangat, membuat remaja tersebut cenderung melakukan bullying di sekolah, tidak seperti remaja yang menerima dukungan sosial dari orang tuanya, mereka dapat menghindar untuk melakukan bullying.

Anantasari 2006 (dalam Novrian, 2017) menyatakan bahwa jika perilaku anak dapat dipengaruhi karena lingkungan keluarga yang mengarah pada hal-hal negatif seperti kekerasan yang umumnya terjadi, memukul, menendang, memakimaki dengan menggunakan kata kotor, dan menonton acara televisi. Karakter seorang anak yang yang berusaha meniru maka anak akan melakukan hal yang sama seperti yang dilihatnya. Anak-anak juga berpikir bahwa perilaku yang sering diamati adalah wajar.

Yan (2007) menyatakan bahwa sangat penting untuk mengontrol pertumbuhan anak yaitu dengan mengetahui hubungan antara ayah dan anak. Remaja dapat lebih beradaptasi dengan lingkungan sosial jika orang tua memberikan kepercayaan dan rasa aman. Hubungan yang baik ini dapat dibentuk melalui ikatan yang baik antara keluarga dan anak-anak (Novrian, 2017). 
Penelitian yang dilakukan Ardiana (2018) menunjukan bahwa remaja cenderung lebih sedikit terlibat dalam perilaku bullying, baik sebagai pelaku maupun sebagai korban karena dukungan yang diterima dari keluarga terutama orangtua sangat baik (Wang et al., 2009). Orang tua adalah salah satu prediktor keterlibatan anak bullying (Kokkinos, 2013).

\section{Hubungan Peran Teman Sebaya Dengan Perilaku Bullying Pada Remaja di SMAN 5 Depok}

Bullying adalah tindakan agresif yang dilakukan dengan sengaja, dan ada ketidakseimbangan kekuatan yang dapat diulang (Hamidah, 2020). Febriani (2020) memaparkan bahwa faktor - faktor yang mempengaruhi remaja melakukan perundungan pada masa remaja yaitu adanya faktor keluarga, lingkungan teman di sekolah atau di masyarakat, dan kepercayaan pada individu.

Sarwono (2013) menjelaskan bahwa remaja lebih bergantung pada teman sebayanya dari pada orang tuanya. Remaja mempunyai emosional yang kuat dengan gengnya. Solidaritas yang kuat dengan teman sebaya membuat remaja memiliki kontak pribadi yang lebih kuat sehingga remaja dapat lebih mudah terpengaruhi teman sebaya mereka (Sigalingging \& Sianturi, 2019).

Puspita \& Kustanti (2019) menyatakan bahwa remaja akan berpikir mereka ditolak dan tidak dibutuhkan oleh lingkungannya ketika remaja tidak mendapatkan dukungan yang positif dari temannya. Akibatnya, remaja akan merasa tidak berharga dan meningkatkan perilaku agresi dalam dirinya sehingga merasa puas, sedangkan remaja akan merasa kepercayaan dirinya semakin tumbuh dan lebih berharga ketika mendapatkan dukungan. Latief (2015) juga menjelaskan bahwa sebagai komunitas kecil pasca-keluarga, teman sebaya memiliki tanggung jawab penting untuk pembentukan karakter, perilaku pembentukan kepribadian, dan pengembangan manusia di bidang akademik dan sosial, yang menunjukkan bahwa interaksi teman sebaya dapat mempengaruhi perilaku yang baik dan kurang baik.

\section{Simpulan}

\section{SIMPULAN DAN SARAN}

Simpulan penelititan yang dapat diambil yaitu: untuk Usia remaja dan jenis kelamin di SMAN 5 Depok tidak ada hubungan dengan perilaku bullying. Karena perilaku bullying bisa dilakukan oleh siapa saja baik laki-laki maupun perempuan dan tidak memandang umur. Ada hubungan positif antara fungsi keluarga dengan perilaku bullying pada remaja SMAN 5 Depok, terbukanya komunikasi didalam keluarga, keluarga yang harmonis dan bahagia maka akan mengarah pada fakta kecendurungan remaja untuk melakukan perilaku bullying akan rendah, begitu pula sebaliknya. ada hubungan positif antara peran teman sebaya dengan perilaku bullying pada remaja SMAN 5 Depok hal ini menandakan bahwa semakin baiknya interaksi serta pergaulan yang positif yang terjalin pada remaja maka menyebabkan remaja untuk menghindari perilaku bullying.

\section{Saran}

Disarankan bagi sekolah mengadakan sosialisasi dan bimbingan konseling secara rutin kepada siswanya. Pihak sekolah sebaiknya juga memasang posterposter anti bullying, pengawasan yang ketat dan aturan yang tegas pada siswa diruang lingkup sekolah. Disamping itu, bagi remaja hendaknya mengetahui tentang bullying supaya lebih menghargai sesama teman, dengan cara tidak 
menyakiti atau mengejek teman yang lain. Hendaknya juga kepada perawat puskesmas mendampingi guru pembina dan siswa/I penggerak program Unit Kesehatan Sekolah/UKS terkait konseling perilaku remaja.

\section{DAFTAR PUSTAKA}

Aminah, A., \& Nurdianah, F. (2019). Pengaruh Teman Sebaya Terhadap Perilaku Bullying Siswa. Jurnal Bimbingan Dan Konseling, 1(1), 1-10.

Ardiana, N. (2018). Tekanan teman sebaya sebagai moderator pada pengaruh keberfungsian keluarga terhadap perilaku.

Fataruba, R. (2016). Peran Teman Sebaya terhadap Perilaku Bullying pada remaja di Sekolah. Tesis. Universitas Muhammadiyah Malang.

Fatmawati, L. (2016). Perbedaan Perilaku Bullying Di Tinjau Dari Jenis Kelamin. Skripsi. Universitas MUhammadiyah Surakarta.

Febriani, N. (2020). Peran Harga Diri, Dukungan Teman Sebaya, Dan Komunikasi Orangtua Terhadap Perilaku Perundungan Siber Pada Remaja. Skripsi. Universitas Muhammadiyah Surakarta.

Febriyani, Y. A., \& Indrawati, E. S. (2017). Konformitas teman sebaya dan perilaku bullying pada siswa kelas XI IPS. Empati, 5(1), 138-143.

Halimah, A., Khumas, A., \& Zainuddin, K. (2015). Persepsi pada bystander terhadap intensitas bullying pada siswa SMP. Jurnal Psikologi, 42(2), 129140.

Hamidah, M. (2020). Religiusitas dan Perilaku Bullying Pada Santri Di Pondok Pesantren. Journal psycho Holistic, 2(1), 141-151.

Hermalinda, Deswita, \& Oktarina, E. (2017). Hubungan karakteristik remaja dengan perilaku bullying pada siswa SMP Di Kota Padang. Jurnal Keperawatan Soedirman, 12(1), 1-11.

Juliyanti, N., \& Siswati, S. (2014). Hubungan Antara Keberfungsian Keluarga Dengan Pengungkapan Diri Remaja Terhadap Orangtua Pada Siswa SMA Krista Mitra Semarang. Empati, 3(4), 422-431.

Karina, Hastuti, D., \& Alfiasari. (2013). Perilaku bullying dan karakter remaja serta kaitannya dengan karakteristik keluarga dan peer group. Jurnal Ilmu Keluarga \& Konsumen, 6(1), 20-29.

Kokkinos, C. M. (2013). Bullying and Victimization in Early Adolescence: Associations With Attachment Style and Perceived Parenting. Journal Of School Violence, (12(2)).

Latief, P. M. (2015). Hubungan AntaraPersepsi Dukungan Sosial Teman Sebaya Dengan Prokrastinasi Akademik Siswa Kelas XI Di SMA Negeri 1Prambanan. Jurnal Riset Mahasiawa Bimbingan Dan Konseling, 4(10).

Marela, G., Wahab, A., \& Marchira, C. R. (2017). Bullying Verbal Menyebabkan Depresi Remaja SMA Kota Yogyakarta. jurnal of community medicine and public health, 33(1), 43. https://doi.org/10.22146/bkm.8183

Morbidity and Mortality Weekly Report. (2011). Bullying among middleschool and high school students - massachusetts. Morbidity and Mortality Weekly Report, 60(15), 465-471.

Ningrum, R. E. C., Matulessy, A., \& Rini, R. A. P. (2019). Hubungan antara Konformitas Teman Sebaya dan Regulasi Emosi dengan Kecenderungan Perilaku Bullying pada Remaja. Jurnal Pemikiran dan Penelitian Psikologi, 
15(1), 124. https://doi.org/10.32528/ins.v15i1.1669

Novrian, A. (2017). Hubungan Antara Fungsi Keluarga Dengan Kecenderungan Perilaku Bullying Pada Remaja Muslim Kelas IX SMP Negeri 3 Palembang. Skripsi. Uin Raden Fatah Palembang.

Puspita, V. D., \& Kustanti, E. R. (2019). Hubungan antara Dukungan Sosial Teman Sebaya dengan Perundungan pada Siswa SMP PL Domenico Savio Semarang. Empati, 7(4), 252-259.

Putri, H. N., Nauli, E. A., \& Novayelindi, R. (2015). Faktor-faktor Yang Berhubungan Dengan Perilaku Bullying Pada Remaja. Cybrarians Journal, 2(37), 1-31. https://doi.org/10.12816/0013114

Rohimah, A. (2016). Hubungan Peran Kelompok Teman Sebaya Dengan PerilakuBullying Pada Anak Usia Sekolah Di Sd Muhammadiyah Mlangi Gamping Sleman Yogyakarta. Universitas Aisyiah Yogyakarat.

Sakdiyah, F., Febriana, B., \& Setyowati, W. E. (2020). Resiliensi dan Kejadian Bullying pada Remaja SMP di Demak. Bima Nursing Journal, 1(2), 83-89.

Sarwono, S. W. (2013). Psikologi remaja(Edisi Revisi). Jakarta: RajawaliPers.

Schwab, J. J., Gray-Ice, H. M., \& Prentice, F. R. (2002). Background, Research Methods, and the Epidemiologic Study. Family Functioning: The General Living Systems Research Model, 119-136.

Sigalingging, G., \& Sianturi, I. A. (2019). Hubungan Teman Sebaya dengan Perilaku Seksual Remaja di SMK Medan Area Medan Sunggal. Jurnal Darma Agung Husada, 5(1), 9-15.

Sitasari, N. W. (2017). Persepsi Tentang Perilaku Bullying Ditinjau dari Jenis Kelamin. Jurnal Psikologi: Media Ilmiah Psikologi, 15(2).

Slonje, R., \& Smith, P. K. (2008). Cyberbullying: Another main type of bullying? Scandinavian Journal of Psychology, 49, 147-154.

Velki, T. (2012). A comparison ofindividual characteristics and the multiple contexts for childrenwith different bullying status: anecologicalperspective. International Journal of Arts \& Sciences, 5(7), 89-112.

Wakhid, A., Andriani, N. S., \& Saparwati, M. (2019). Perilaku Bullying Siswa Usia 10-12 Tahun. Jurnal Keperawatan Jiwa, 5(1), 25. https://doi.org/10.26714/jkj.5.1.2017.25-28

Wardani, L. K., \& Fajriansyah. (2017). Perilaku Bullying Mahasiswa Kesehatan. Journal Of Nursing Practice, 1(1), 17-23.

Wiyani, novan A. (2012). Save Our Children from School Bullying. Jogjakarta : Ar-Ruzz Media.

Zakiyah, E. Z., Humaedi, S., \& Santoso, M. B. (2017). Faktor Yang Mempengaruhi Remaja Dalam Melakukan Bullying. Jurnal Penelitian \& PPM, 4(2), 324330. https://doi.org/10.24198/jppm.v4i2.14352 